\title{
Persepsi Kelompok Tani terhadap Peranan Penyuluh Pertanian di Kecamatan Rantau Utara Kabupaten Labuhan Batu
}

\section{The Perception Of Farmer Groups On The Role Of Agriculture Extension In North Rantau District, Labuhan Batu District}

\author{
Joni Rianto Siregar'1), Rahmanta Ginting2), Ihsan Effendi ${ }^{3}$ )
}

1) Program Studi Magister Agribisnis, Pascasarjana, Universitas Medan Area, Indonesia

2) Departemen Agribisnis, Fakultas Pertanian, Universitas Sumatera Utara, Indonesia

3) Magister Agribisnis, Pascasarjana, Universitas Medan Area, Indonesia

\begin{abstract}
Abstrak
Tujuan penelitian ini mendeskripsikan Persepsi Kelompok Tani Terhadap Peran Penyuluh Pertanian dalam pengembangan Kelompok tani di Kecamatan Rantau Utara Kabupaten Labuhanbatu dan mengetahui kendala yang dihadapi oleh penyuluh dalam kegiatan penyuluhan pada kelompok tani di Nagari Sungai Pua, Kecamatan Sungai Pua, Kabupaten Agam. Penelitian ini merupakan penelitian survei, menggunakan responden yang dipilih dengan menggunakan metode sampling bertahap (multistage sampling) dengan memilih 7 dari 68 kelompok tani dan memilih 79 responden dari kelompok tani terpilih, yang dilakukan secara sengaja (purposive). Data di analisis secara deskriptif kuantitatif dan kualitatif. Hasil penelitian menunjukan bahwa peran penyuluh sebagai penyuluh motivator, edukator, organisator, dan komunikator dikategorikan berperan, sedangkan peran penyuluh sebagai katalisator dan konsultan dikategorikan tidak berperan. Dari hasil ini disarankan agar penyuluh diharapkan lebih meningkatkan kontribusinya dengan membantu petani dalam memecahkan masalah, membantu proses dilapangan dan menghubungkan petani dengan sumber teknologi.

Kata Kunci: Peran Penyuluh, Kelompok Tani, Persepsi
\end{abstract}

\begin{abstract}
The purpose of this study is to describe Farmers Group Perceptions of the Role of Agricultural Extension Workers in the development of Farmer Groups in Rantau Utara District, Labuhanbatu Regency and find out related to extension agents in various training programs for farmer groups in Nagari Sungai Pua, Sungai Pua District, Agam District. This research is a survey research, using selected respondents using a multistage sampling method by selecting 7 out of 68 farmer groups and choosing 79 respondents from selected farmer groups, which is carried out intentionally. Data were analyzed descriptively quantitative and qualitative. The results showed that the role of instructors as motivators of educators, instructors, administrators, and communicators was categorized in participation, while the role of instructors as catalysts and consultants was categorized as not supportive. From this result it was agreed that extension agents were expected to further increase their contribution by assisting farmers in solving problems, assisting the process in the field and connecting farmers with technology sources.
\end{abstract}

Keywords: Role of Instructor, Farmer Group, Perception

How to Cite: Siregar, J.R., R. Ginting, \& I. Effendi. (2019). Persepsi Kelompok Tani terhadap Peranan Penyuluh Pertanian di Kecamatan Rantau Utara Kabupaten Labuhan Batu. Jurnal Ilmiah Magister Agribisnis, 1(2) 2019: 129-137,

*E-mail: ihsaneffendi@uma.ac.id ISSN 2550-1305 (Online)

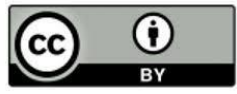


Siregar, J.R., R. Ginting, \& I. Effendi. Persepsi Kelompok Tani terhadap Peranan Penyuluh Pertanian di Kecamatan Rantau Utara Kabupaten Labuhan Batu.

\section{PENDAHULUAN}

Pertanian merupakan salah satu sektor utama yang menopang kehidupan masyarakat, karena sektor pertanian menjadi mata pencarian sebagian besar penduduk Indonesia. Berangkat dari hal tersebut, maka pertanian merupakan salah satu penopang perekonomian nasional. Artinya bahwa sektor pertanian memegang peran penting san seharusnya menjadi penggerak dari kegiatan perekonomian. berdasarkan data BPS 2014, penduduk yang bekerja di sektor pertanian berjumlah sekitar 38,973,033 orang atau $40 \%$ dari total penduduk usia produktif, Sedangkan sisanya sebanyak 60 persen tersebut diberbagai sektor diluar pertanian. Sektor pertanian sendiri dalam penerapannya terbagi dalam berbagai macam sub sektor. Di Indonesia sektor pertanian terbagi menjadi lima, yaitu pertama sub sub sektor tanaman pangan, kedua sub sektor perkebunan, ketiga sub sektor hortikultura, keempat sub sektor peternakan, dan kelima adalah sub sub sektor perikanan (Mubyarto,1989). Oleh karena itu, dibutuhkannya kegiatan penyuluh penyuluh pertanian yang mampu mencukupi kebutuhan petani dalam hal kegiatan pertanian.

Penyuluhan pertanian merupakan pendidikan non formal bagi petani yang meliputi kegiatan dalam ahli pengetahuan dan keterampilan dari penyuluh kepada petani dan keluarganya yang berlangsung melalui proses belajar mengajar (Mardikanto, 2011). Penyuluh pertanian harus ahli pertanian yang berkompeten, disamping bisa membimbing para petani, penyuluh juga memberikan motivasi, memberikan informasi dan meningkatkan kesadaran petani sehinngga dapat mendorong minat belajar mereka dalam menghadapi permasalahan dilapangan.

Petani adalah pelaku utama dalam kegiatan produksi pertanian serta bagian dari masyarakat Indonesia yang perlu ditingkatkan kesejateraan dan kecerdasannya, salah satu upaya peningkatan kecerdasan tersebut dilaksanakan melalui kegiatan penyuluhan. Dengan adanya penyuluh diharapkan semua informasi pertanian yang berkembang dapat diserap dan diterima oleh petani. semakin banyak informasi yang dimanfaatkan oleh petani maka semankin efektif penyuluhan tersebut.

Penyuluh dapat mempengaruhi sasaran melalui perannya melalui edukasi, inovas, fasilitasi, konsultasi, supervisi, pemantauan, evaluasi maupun sebagai penasehat petani (Mardikanto, 2009) yang sesuai dengan karakteristik/ciri petani termasuk potensi wilayah. Untuk meningkatkan efektivitas dari kegiatan penyuluhan dan guna menumbuhdan mengembangkan peran serta petani dalam pembangunan pertanian, maka perlu dilakukan pembinaan terhadap kelompok tani yang terbentuk sehingga nantinya kelompok tani tersebut akan mampu untuk tumbuh dan berkembang menjadi kekuatan ekonomi yang memadai dan selanjutnya akan mampu menopang kesejateraan anggotanya. Pengembangan kelompok tani merupakan serangkaian proses kegiatan memampukan/ memberdayakan kumpulan anggota kelompok tani untuk mempunyai tujuan bersama.

Kelompok tani dikatakan berkembang apabila memiliki karakteristik yang berciri sebagai berikut : a) Saling mengenal, akrab dan saling percaya diantara sesama anggota, b) Mempunyai pandangan dan kepentingan yang sama dalam berusaha tani, c) Memiliki 
kesamaan dalam tradisi atau pemukiman, hampaan usaha, jenis usaha, status ekonomi maupun sosial, bahasa, pendidikan dan ekologi, d) Ada pembagian tugas dan tanggung jawab sesama anggota berdasarkan kesepakatan bersama (Deptan, 2007) .

Peran penyuluh dalam pengembangan kelompok tani perlu dilaksanakan dengan nuansa partisipatif sehingga prinsip, transparansi, tanggung jawab, akuntabilitas serta kerjasama menjadi muatan-muatan baru alam pemberdayaan petani. Suatu kelompok tani yang terbentuk atas dasar adanya kesamaan kepentingan diantara petani menjadikan kelompok tani tersebut dapa eksis dan memiliki kemampuan untuk melakukan akses kepada seluruh sumber daya seperti sumber daya alam, manual, model, informasi, serta sarana dan prasarana dalam mengembangkan usaha tani yang dilakukannya (Jasmal, 2007). Wujud dari kegiatan penyuluhan dalam pengembangan kelompok tani bisa dicerminkan dengan adanya pertemuan anggota kelompok secara rutin dan kegiatan gotong royong yang didampingi oleh penyuluh. Oleh karena itu tujuan penelitian ini untuk menganalisa peranan penyuluh pertanian dalam pengembangan kelompok Tani Dalam meningkatkan produksi Padi di Kecamatan Rantau Utara Kabupaten Labuhan Batu dan menganalisa kendala yang dihadapi oleh penyuluh dalam kegiatan penyuluh pada Kelompok Tani di Kecamatan Rantau Utara Kabupaten Labuhan Batu.

\section{METODE PENELITIAN}

Penelitian dilaksanakan di Kecamatan rantau Utara, Kabupaten Labuhan Batu . Pemilihan tempat penelitian ini dilakukan secara sengaja atau purposif, dengan pertimbangan bahwa daerah Kecamatan Rantau Utara merupakan daerah yang potensial untuk kegiatan produksi pertanian, baik dari faktor alamnya yang strategis, maupun dari faktor luas lahan yang lebih besar dari Kecamatan lainnya. Penelitian ini dilaksanakan selama Bulan Juli - Oktober 2017. Data yang digunakan dalam penelitian ini adalah Data deskriptif dengan jenis survei (survey). Jumlah sampel dalam penelitian ini adalah 97 sampel.

Data yang diamati pada penelitian ini adalah peran penyuluh pertanian dalam Meningkatkan Produksi Padi sawah di Kecamatan Rantau Utara Kabupaten Labuhan Batu dalam satu tahun terakhir yaitu pada tahun 2015. Penelitian ini dianalisis secara deskriptif kualitatif dengan metode skoring

\section{HASIL DAN PEMBAHASAN}

\section{Identitas dan Karakteristik Petani Responden}

Identitas dan karekteristik petani responden, petani responden merupakan anggota dari kelompok tani Kecamatan Rantau Utara . Jumlah responden dalam penelitian ini sebanyak 68 Kelompok Tani yang berhubungan dengan peran penyuluh dalam pengambangan kelompok tani tersebut. Dimana dalam menentukan responden dilakukan secara sengaja (purposive sampling) yaitu memilih orang yang berkaitan dengan petani anggota kelompok dalam melaksanakan pekerjaannya. Identifikasi ini meliputi : umur, jenis kelamin, pendidikan, luas lahan, status pemilikan lahan, jumlah tanggungan keluarga dan jumlah kehadiran dalam rapat kelompok tani baik itu kehadiran bulanan dan tahunan kegiatan tersebut merupakan kegiatan 
Siregar, J.R., R. Ginting, \& I. Effendi. Persepsi Kelompok Tani terhadap Peranan Penyuluh Pertanian di Kecamatan Rantau Utara Kabupaten Labuhan Batu.

yang bersifat rutinitas sehingga dapat mengkontrol atau mengawasi semua kelompok yang terlibat dalam setiap kegiatan.

Tabel 1. Identitas Petani Responden Pada Kelompok Tani Tahun 2017

\begin{tabular}{|c|c|c|c|}
\hline No & Ketengan & Jumlah (Orang) & Persen (\%) \\
\hline \multirow[t]{4}{*}{1} & Umur ( Tahun) & & \\
\hline & a. $<30$ & 5 & $16 \%$ \\
\hline & b. $30-50$ & 19 & $64 \%$ \\
\hline & c. $>50$ & 6 & $20 \%$ \\
\hline \multirow[t]{5}{*}{2} & Pendidikan & & \\
\hline & a. $\mathrm{SD}$ & 8 & $27 \%$ \\
\hline & b. SLTP & 9 & $30 \%$ \\
\hline & c. SLTA & 11 & $37 \%$ \\
\hline & d. $\quad$ D3 & 2 & $6 \%$ \\
\hline \multirow[t]{4}{*}{3} & Luas Lahan & & \\
\hline & a. $0,10-0,30 \mathrm{Ha}$ & 1 & $3 \%$ \\
\hline & b. $0,31-0,50 \mathrm{Ha}$ & 30 & $67 \%$ \\
\hline & c. $0,51-1 \mathrm{HA}$ & 9 & 30 \\
\hline \multirow[t]{3}{*}{4} & Status Kemilikan Lahan & & \\
\hline & a. Milik Sendiri & 38 & $87 \%$ \\
\hline & b. Sewa dan milik sendiri & 4 & $13 \%$ \\
\hline \multirow[t]{4}{*}{5} & Jumlah Anggota Keluarga & & \\
\hline & a. $1-3$ & 10 & $33 \%$ \\
\hline & b. $4-6$ & 14 & $47 \%$ \\
\hline & c. Lebih dari 6 & 6 & $20 \%$ \\
\hline \multirow[t]{4}{*}{6} & Kehadiran dalam rapat kelompok & & \\
\hline & a. $\quad<3$ kali & 5 & $17 \%$ \\
\hline & b. 3-5 kali & 10 & $33 \%$ \\
\hline & c. 8 kali & 15 & $50 \%$ \\
\hline
\end{tabular}

Sumber : Kantor BPP Kec. Rantau Utara 2017

Peran Penyuluh Pertanian Dalam Pengembangan Kelompok Tani Madya Dari Tabel 10 dapat dilihat bahwa rata - rata responden berusia 30 tahun (64\%) pada kategori usia tersebut responden digolongkan pada usia produktif karena kemampuan fisik untuk melakukan pekerjaan disektor usaha tani masih tinggi.

Dilihat dari pendidikan formalnya, sebagian besar responden rata - rata berpendidikan SLTA sebanyak 11 orang (37\%). Dengan demikian dapat diketahui bahwa tingkat pendidikan responden sudah tergolong lumayan tinggi karena banyak antara meraka tamatan SLTA dan tidak ada yang tidak bersekolah. Tingginya tingkat pendidikan responden disebabkan adanya kesadaran petani akan pentingnya pendidikan formal yang memudahkan penyuluh dalam memberikan materi penyuluhnya.

Untuk luas lahan yang dimiliki oleh petani responden rata - rata petani memiliki luas lahan sebesar 0,31-0,51 Ha sebanyak 30 orang (67\%). Sedangkan untuk status kepemilikan lahan rata - rata lahan milik sendiri dengan presentase $87 \%$ atau sebanyak 38 orang responden.

Jumlah tanggungan keluarga juga akan mempengaruhi pada tingkat kesejahteraan terutama pada keluarga yang mempunyai tingkat pendapatan yang rendah. Rata - rata jumlah tanggungan responden sebanyak 4-6 orang berjumlah 20 orang (48\%). Dilihat dari kehadiran responden petani saat mengikuti rapat, umumnya responden petani hadir dalam mengikuti 
kegiatan dalam kelompok 8 kali yaitu sebanyak 15 orang (50\%) yang menunjukan adanya respon petani dalam memajukan usaha dalam kelompok tani.

Semua kelompok tani selalu terlibat dalam kegiatan di setiap kelompoknya dan harus memiliki agenda masing - masing untuk di bawah ke dalam forum rapat, dalam hai ini petani selaku pelaku utama dalam kegiatan kelompok tani harus lebih memiliki kemauan untuk merubah prinsip untuk menerima pengetahuan dari penyuluh - penyuluh yang memberikan informasi demi menambah pengetahuan.

\section{Peran Penyuluh Pertanian Dalam Pengembangan Kelompok Tani}

\begin{tabular}{|c|c|c|c|c|c|c|c|}
\hline No & $\begin{array}{c}\text { Peran } \\
\text { Penyuluh }\end{array}$ & $\begin{array}{l}\text { Madya } \\
\text { (skor) }\end{array}$ & Kategori & $\begin{array}{l}\text { Lanjut } \\
\text { (skor) }\end{array}$ & Kategori & $\begin{array}{l}\text { Pemula } \\
\text { (skor) }\end{array}$ & Kategori \\
\hline 1 & Motivator & 95 & Berperan & 206 & Berperan & 226 & Berperan \\
\hline 2 & Edukator & 86 & Berperan & 217 & Berperan & 217 & Berperan \\
\hline 3 & Katalisator & 48 & $\begin{array}{c}\text { Tdk } \\
\text { berperan }\end{array}$ & 111 & $\begin{array}{c}\text { Tdk } \\
\text { berperan }\end{array}$ & 96 & $\begin{array}{c}\text { Tdk } \\
\text { berperan }\end{array}$ \\
\hline 4 & Organisator & 83 & Berperan & 218 & Berperan & 230 & Berperan \\
\hline 5 & Komunikator & 82 & Berperan & 246 & Berperan & 231 & Berperan \\
\hline 6 & Konsultan & 37 & $\begin{array}{c}\text { Tdk } \\
\text { berperan }\end{array}$ & 160 & $\begin{array}{c}\text { Tdk } \\
\text { berperan }\end{array}$ & 155 & $\begin{array}{c}\text { Tdk } \\
\text { berperan }\end{array}$ \\
\hline & Total & 431 & & 1.158 & & 1.155 & \\
\hline
\end{tabular}

Sumber : Data Primer (diolah), 2017

Dari tabel 2 dapat dilihat bahwa peran penyuluh kelompok tani madya, kelompok tani lanjut, dan kelompok tani pemula sebagai motivator adalah berperan. Sebagian besar petani berpendapat bahwa penyuluh sudah mendorong petani untuk mengembangkan usahanya, membantu dalam memudahkan penggunaan teknologi serta sudah membantu petani dalam mengarahkan usahataninya.

Peran penyuluh sebagai edukator pada kelompok tani madya memperoleh skor 86. Petani merasa bahwa materi yang disampaikan penyuluh dapat diterima oleh petani, penyuluh menguasai materi yang akan disampaikan, salah satu contoh penyuluh berperan dalam meningkatkan pengetahuan petani yaitu dengan menyampaikan bagaimana cara mengurangi terjadinya lossis pada saat panen dengan menggunakan alas pada onggokan. Pada kelompok tani lanjut dan pemula petani responden yang menyatakan penyuluh berperan dalam meningkatkan pengetahuan petani dengan skor secara berurutan 217 dan 217. Alasan petani menyatakan berperan yaitu penyuluh sudah memyampaikan banyak informasi mulai dari inovasi - inovasi terbaru untuk kemajuan petani dan organik, pestisida organik, pengaturan jarak tanam dengan sistem jajar legowo dll. informasi dan teknologi yang disampaikan penyuluh pertanian tidak terbatas pada bidang pertanian saja, tetapi juga mencakup bidang - bidang lainnya yang berhubungan dengan bidang ekonomi yang menyangkut kredit. Peran penyuluh pada kelompkok tani tingkat lanjut juga sudah berperan. Alasan petani menyatakan penyuluh berperan karena penyuluh memberikan pelatihan tentang pengandalian hama penyakit, penyuluh juga meningkatkan pengetahuan petani dengan memberikan materi sesuai dengan yang dibutuhkan oleh kelompok tani. Pengukuran peran penyuluh pertanian dalam pengembangan kelompok tani dimaksudkan untuk mengukur bagaimana peran penyuluh sebagai educator dalam kelompok tani.

Peran penyuluh kelompok tani madya sebagai katalisator adalah tidak berperan, dengan perolahan skor 48. Hal tersebut menunjukan penyuluh sebagai katalisator belum 
dapat menyampaikan aspirasi petani kepada Pemerintah. Alasan petani menilai penyuluh belum ada menyampaikan kebijakan dan peraturan dibidang pertanian, petani tidak ada mendapatkan informasi dari penyuluh. Begitu juga pada kelompok tani lanjut dan pemula yang berpendapat bahwa penyuluh juga tidak berperan dengan skor 111 dan 96. Petani responden yang menyatakan penyuluh tidak berperan dalam menyampaikan kebijakan dan peraturan di bidang pertanian. Petani menyatakan penyuluh tidak berperan karena tidak adanya kerjasama yang terbentuk antara kelompok tani dengan pihak lain.

Peran penyuluh pada kelompok tani madya sebagai organisator adalah berperan, dengan perolehan skor 80. Alasan petani setuju penyuluh berperan yaitu penyuluh berdiskusi bersama dengan petani dalam menentukan jadwal pertemuan dengan anggota kelompok tani, serta memberikan kesempatan kepada kelompok tani untuk bertanya satu sama lainnya dalam hal yang berhubungan dengan usaha tanaman padi. Begitupula pada kelompok tani lanjut dengan skor 218. Alasan petani setuju penyuluh berperan yaitu penyuluh berdiskusi bersama dengan petani dalam menentukan jadwal penentuan dengan anggota kelompok tani serta memberikan kesempatan kepada anggota kelompok tani, serta memberikan kesempatan kepada kelompok tani untuk bertanya satu sama lainnta dalam hal berhubungan dengan usaha tanaman padi. anggota kelompok menilai bahwa penyuluh membantu menyusun jadwal bersama kegiatan kelompok tani, membantu membuat pembagian tugas didalam kelompok, dan menganjurkan petani untuk mengadakan temu langsung sebagai media komunikasi antar kelompok. Kelompok tani pemula juga berpendapat bahwa penyuluh juga berperan dengan skor 230. Alasan petani setuju penyuluh berperan yaitu penyuluh berdiskusi bersama dengan petani dalam menentukan jadwal penentuan dengan anggota kelompok tani serta memberikan kesempatan kepada anggota kelompok tani, serta memberikan kesempatan kepada kelompok tani untuk bertanya satu sama lainnta dalam hal berhubungan dengan usaha tanaman padi. Anggota kelompok menilai bahwa penyuluh membantu menyusun jadwal bersama kegiatan kelompok tani, membantu membuat pembagian tugas didalam kelompok, dan menganjurkan petani untuk mengadakan temu langsung sebagai media komunikasi antar kelompok. Penyuluh membantu petani dalam hal merencanakan tanaman apa yang akan ditanam sesuai dengan musimnya, tujuannya agar mengurangi resiko kerugian yang dihadapi petani.

Peran penyuluh sebagai komunikator adalah berperan, dengan perolehan skor 82 pada kelompok tani madya. Petani menyatakan penyuluh berperan dalam membantu percepatan informasi yaitu penyuluh memyampaikan informasi dengan cara mensosialisasikannya kepada anggota kelompok tani, serta memerlihatkan bukti - bukti keberhasilan dalam mengusahakan tanaman padi kelompok. Petani meyatakan penyuluh beperan yaitu, karena sewaktu pemberian materi penyuluh menanyakan apakah anggota sudah menguasai dan paham terhadap teknologi tersebut. Sehingga petani mengetahui cara mana yang akan dipilih/dilakukan nanti. Sedangkan pada kelompok tani lanjut diperoleh skor 246 yang masuk dalam kategori berperan, begitupula pada kelompok tani pemula dengan skor 231.

Peran penyuluh sebagai konsultan adalah tidak berperan pada ketiga tingkatan kelompok tani. Sebagian petani berpendapat bahwa penyuluh hanya menyampaikan informasi saja, dalam identifikasi masalah yang dihadapi kelompok. Penyuluh belum membantu untuk menyelesaikan masalah, baik masalah yang berkaitan dengan produksi maupun usaha tani mulai dari bibit, tanah, hama, penyakit, panen dan pemasaran, maupun masalah - masalah yang berhubungan dengan administrasi kelompok. Petani mengatakan penyuluh hanya memberikan materi yang sudah dijadwalkan. 
Tabel 3. Hasil Keseluruhan Peran Penyuluh

\begin{tabular}{ccl}
\hline Kelas Kelompok & Skor & Katagori \\
\hline Madya & 431 & Beperan \\
Lanjut & 1.158 & Beperan \\
Pemula & 1.155 & Beperan \\
\hline Total Nilai & 2.734 & Beperan \\
\hline
\end{tabular}

Sumber : Data Primer (diolah), 2017

Dapat dilihat pada Tabel 3 bahwa telah berperan menjalankan tugasnya sebagai motivator, edukator, organisator, dan konsultan. Namum pada kelas kelompok madya, lanjut, dan pemula menyatakan peran penyuluh sebagai katalisator tidak berperan. Dikarenakan penyuluh hanya sebagai pendamping lapangan, penyuluh memberikan masukan ketika petani memintanya. Penyuluh hanya berkunjung sesuai dengan waktu yag telah dijadwalkan. Sebagai penyuluh katalisator seharusnya penyuluh harus bertindak antara lain adalah menyampaikan aspirasi petani, menyampaikan kebijakan dan peraturan dibidang pertanian.

Adanya keluhan - keluhan dari petan terhadap permasalahan yang dihadapi seperti masalah budidaya tanaman padi (Pembibitan, Pola tanam, pemanenan dll), pemupukan (cara pemberian dosis pupuk), pengendalian hama dan penyakit tanaman dan pasca panen. Dari permasalahan tersebut maka penyuluh dapat berperab sebagai penghubung dalam menyampaikan informasi - informasi baik dari instasi terkait maupun dari media sosiaol materi yang diberikan penyuluh disesuaikan dengan kebutuhan kelompok tani itu sendiri dalam menjalankan usahataninya.

Pernyataan dari masing - masing kelompok tani hampir semuanya sama,dikarenakan dalam memberikan penyuluhan tidak ada perbedaan antar kelas kelompok madya, kelas kelompok lanjut, dan kelompok pemula penyuluh memberikan materi yang sama. Pada umumnnya tatanama yang diusahakan kelompok tani sama, sehinggga penyuluh memberikan penyuluhan yang sama terhadap masing - masing kelompok tani.

\section{Permasalahan Yang Dihadapi Kelompok Tani}

Dalam pelaksanaan penyuluh dalam pengembangan kelompok tani, dibina dan luas wilayah yang harus ditangani. Penyuluh harus menjalankan kelompok tani, dalam pengembangan kelompok tani ini Penyuluh dikatagorikan kedalam enam katagori yaitu, motivator, edukator, katalisator, organisator, komunikator, dan juga konsultan. Dari enam katagori yang ada dan didalamnya dikatagorikan peran penyuluh tidak berperan, yaitu katalisator dan konsultan. Sebelum mengganti dan menentukan kebutuhan kelompok tani, penyuluh terlebih dahulu melihat bagaimana keadaan dan permasalahan yang dihadapi petani di daerah penelitian. Setelah itu, penyuluh segera merencanakan dan mempersiapkan kebutuhan kelompok tani dengan keadaan dan permasalahan yang dihadapi kelompok tani.

Kendala Penyuluh Sebagai Motivator

Penyuluh selalu memberikan motivasi pada saat pertemuan berlangsung, walaupun penyuluh masih mengalami kesulitan dalam menumbuhkan kedisplinan dan motivasi anggota kelompok tani disebabkan kerusakan berkelompok dari petani masih belum ada. Namum penyuluh mengatasinya dengan cara menggambarkan dan membandingkan dengan kelompok tani yang telah berhasil agar menumbuhkan semangat dari masing - masing anggota kelompok tani. Yang dijadikan responden penelitian mengukur penyuluh telah memberikan motivasi dan kelompok tani sendiri merasa adanya perubahan sejak anggota kelompok. Bagaimana yang dijelaskan. 
Kelompok tani merasakan adanya perubahan disiplin dan motivasi anggota kelompok, sehingga dalam mengadakan setiap kegiatan - kegiatan kelompok, anggota kelompok tani hadir pada saat dilakukan kegiatan - kegiatan kelompok tani .

Kendala Penyuluh Sebagai Edukator

Sangat sulit dalam melaksanakan proses pertemuan dan pembelajaran secara konduktif disebabkan kesibukan individual terutama petani hortikultura. Dari sisi kelompok tani seorang anggota kelompok tani menjelaskan bahwa anggota kelompok memiliki kesibukan sendiri-sendiri dalam kegiatan usaha lainnya sehingga sulit untuk dikumpulkan. Oleh karena itu penyuluh terkendala dalam mewujudkan lingkungan belajar yang sesuai.

Kendala Penyuluh Sebagai Katalisator

Penyuluh masih belum mampu mengarahkan kelompok agar mampu menjalin kerja sama dalam meraih informasi. Hal ini terlihat ketika hubungan kerja sama kelompok ketika kegiatan penyuluhan. Salah satu responden mengatakan bahwa "Kegiatan berkelompok belajar dan bertukar informasi sangat jarang terjadi terutama ketika diluar kegiatan yang diadakan penyuluh karena untuk berkumpul diluar kegiatan sulit, dan pada saat kami membutuhkan dampingan penyuluh tidak ada ditempat." Penyuluh pertanian mejelaskan "Disini penyuluh hanya bisa mendapingi pada saat jadwal yang ditetapkan. Sehingga dilapangan seringkali sulit dalam menemui kelompok untuk mengadakan pertemuan dan agenda kegiatan diluar jadwal yang telah ditetapkan." Sehingga dapat dikatakan kegiatan pembinaan hanya dapat dilaksanakan pada saat jadwal yang telah ditetapkan dan jadwal antara petani dan pemerintah kadang tidak sinkron dalam mendukungnya kegiatan penyuluhan karena tidak adanya penambahan tenaga penyuluhan.

Kendala Penyuluh Sebagai Organisator

Dalam kegiatan - kegiatan penyuluhan, kelompok terkesan pasif dalam melakukan kegiatan belajar, namum dalam hal ini penyuluh mengakui telah menghimbau dan memberikan kesempatan secara berulang, agar setiap anggta kelompok aktif untuk berpartisipasi seperti yang disampaikan oleh penyuluh pertanian. Namun dirasakan penyuluh belumlah mampu dalam meciptakan suasana saling kanal, saling percaya mempercayai dan selalu berkeinginan untuk kerjasama dalam kegiatan penyuluhan kelompok tani. Kepala RKPP pertanian Rantau Utara yang sebelumnya juga merupakan penyuluh menambahkan. Dari yang saya lihat, kebanyakan saat ini hanya melakukan kerjasama sebatas program kerjasama saja seperti mesin. Saring kali meraka melupakan dalam sebuag pemberdayaan memerlukan membangun ikatan kerjasama dalam berkelompok, kebanyakan penyuluh kesulitan dalam melaksanakan tugasnya.

Kendala Penyuluh Sebagai Komunikator

Dari sisi kelompok, ketua kelompk tani dan salah satu kelompok tani yang dijadikan responden penelitian mengakui penyuluh telah menjalin komunikasi yang baik, penyuluh berupaya membantu petani dalam membantu percepatan arus informasi pada petani, membantu petani dalam menjalin komunikasi yang baik antar sesama kelompok tani dan membantu petani dalam mengambil keputusan.

Kendala Penyuluh Sebagai Konsultan

Dari sisi kelompok tani, ketua kelompok tani dari salah satu anggota kelompok tani yang dijadikan responden penelitian mengakui penyuluh telah memberikan konsultasi. Kelompok tani merasa adanya perubahan sejak ada penyuluh. Penyuluh berupaya membantu petani dalam memecahkan masalah dilapangan. 


\section{SIMPULAN}

Peran penyuluh dikatagorikan kedalam Penyuluh Kelas Madya, Penyuluh Kelas Lanjut, dan Penyuluh Kelas Pemula. Peran penyuluh pada seluruh kelas kelompok tani masuk dalam kategori berperan. Kendala - kendala yang dihadapi penyuluh dilapangan adalah Penyuluh belum dapat menyampaikan aspirasi petani, kurangnya inovasi yang dapat memajukan usahatani, adanya koneksi penyuluh dengan pihak lain. Kurang terkoordinasinya penyampaian informasi dari Dinas Pertanian. Belum dapat menyampaikan aspirasi petani kepada Pemerintah, belum optimalnya dalam memberikan informasi dan pemecahan masalah petani, tidak semua masalah dapat terpecahkan, dan sulit waktu pertemuan antara penyuluh dan petani karena penyuluh yang hanya berjumlah satu orang, penyuluh tidak ditempat ketika petani membutuhkan saran dan solusi dilapangan.

Peran penyuluh sebagai konsultan dan Katalisator hendaknya lebih ditingkatkan agar terwujud petani yang mandiri dan tidak harus selalu tergantung pada penyuluh. Untuk mengatasi kendala penyuluh di lapangan diperlukan peran dari Pemerintah daerah. Dengan adanya penambahan tenaga kerja penyuluh dari dinas terkait dan memberikan bantuan alat - alat pertanian yang diperlukan petani untuk menunjang kelancaran usahatani petani atau kelompok tani tersebut.

\section{DAFTAR PUSTAKA}

Badan Pusat Stastitik. (2014). Lapangan Pekerjaan Utama Rakyat Indonesia 2013 - 2014 Suvri Angkatan Ketus Nasional (Sekenas) 2012, dan 2014.

Depatermen Pertanian. (2007). Undang - udang Republik Indonesia, Nomor. 14 Tahun 2006. Tentang Sistem Penyuluhan Pertanian, Perikanan dan Kehutanan Jakarta.

Depatermen Pertanian. (2007.).Undang - udang Republik Indonesia, Nomor. 14 Tahun 2007. Tentang Pedoman Pertumbuhan dan Pengambangan Kelompok Tani dan Gabungan Kelompok Tani Jakarta.

Mardikanto, Tolok. (2009). Sistem Penyuluh Pertanian.Universitas Sebelas Maret. Surakarta. 367 Hal

Jasmal. (2007). Catiing Agrohara Maying New York A Penege in Publisher.

Mubyarto, (1989). Pengantar Ekonomi Pertanian, Edisi Ketiga, LP3ES.

Nazir, M. 2005 Metode Penelitian. Ghalia. Jakarta. 210 Hal

Peraturan Menteri Pertanian Nomor 83 Tahun 2013. Tentang Pedoman Pembinaan Kelompok Tani dan Gabungan Kelompok Tani. BKP5K Kabupaten Bogor (ID)

Raharja, Wisnu. 2011. Peran Penyuluh Pertanian Dalam Meningkatkan Kinerja Usaha Tanu (SIap Kasus Tanaman Unggulan Padi di Kabupaten Kudus) Jurusan Ekonomi Pembangunan. Fakultas Ekonomi. Univesitasn Negeri Semarang.

Revikasari, 2010, Peranan Penyuluh Pertanian Dalam pengambangan Gabungan Kelompok Tani (Gapoktani) di Desa Tempuran, Kecamatan Paron Kabupaten Labuhanbatu Ngawi. Universitas Sebelas Maret. Padang. 130 Hal.

Sangadji, E.M. dan Sopiah, (2010), Metodologi Penelitian, Pendekatan Praktis dalam Penelitian, Penerbit Andi, Yogyakarta 385 Hal.

Sumardjo. (2010). Model Pemberdayaan Masyarakat dan Pengololaan Konflik Sosial Pada Perkembinan Kelapa Sawit Di Provinsi Riau. Riau. 287 Hal.

Soedijanto. (2011). Administrasi Pertanian Pusat Pemerintah Universitas Terbuka, Jakarta. 225 Hal. 